\title{
Holistic Diagnosis of Rising Damp and Salt Attack in Two Residential Buildings in Kumasi, Ghana
}

\author{
Kofi Agyekum, ${ }^{1}$ Joshua Ayarkwa, ${ }^{1}$ and Christian Koranteng ${ }^{2}$ \\ ${ }^{1}$ Department of Building Technology, Kwame Nkrumah University of Science and Technology, Kumasi, Ghana \\ ${ }^{2}$ Department of Architecture, Kwame Nkrumah University of Science and Technology, Kumasi, Ghana \\ Correspondence should be addressed to Kofi Agyekum; agyekum.kofil@gmail.com
}

Received 20 May 2014; Accepted 13 July 2014; Published 24 July 2014

Academic Editor: F. Pacheco-Torgal

Copyright (c) 2014 Kofi Agyekum et al. This is an open access article distributed under the Creative Commons Attribution License, which permits unrestricted use, distribution, and reproduction in any medium, provided the original work is properly cited.

\begin{abstract}
Rising damp is one of the most severe phenomena that leads to decay and deterioration of both old and modern types of buildings. This study employed a holistic approach to dampness investigation and sought to examine the problem of rising damp in the walls of two residential apartments in Kumasi, Ghana. The study sought to determine the types of soluble salts and their concentrations in the soils and accumulated percentages in the walls over time and whether there exists any linkage between the salts in the walls and those in the ground. Results from the geotechnical survey of the building sites found that the soils on site 1 consisted of silty sandy gravel with some clay particles and those on site 2 consisted of silty sandy soil with some clay and traces of gravel. The study identified several groups of salts in the walls of the buildings, with the most damaging and dangerous being magnesium sulphate, magnesium chloride, and sodium sulphate salts. Similar salts were identified in the soil samples from the trial pits. The results therefore indicate a linkage between the salts found in the ground and those found in the walls and therefore confirm the presence of rising dampness.
\end{abstract}

\section{Introduction}

All buildings are expected to be constructed with materials which have the tendency to resist the effects of water throughout their service lives [1]. For buildings to perform this function, there is the need for correct design and maintenance throughout their service lives [1]. Moisture that should not be present in buildings is known as dampness [2]. Buildings are said to have dampness problems when the materials in the buildings become sufficiently damp, leading to materials damage or visible mold growth [2].

Ghana, a country with hotter and drier climate, has experienced dampness for several years [3]. In a study to identify the most dominant type(s) of dampness in residential buildings in Ghana, all the surveyed buildings were identified to have symptoms related to either rising dampness, condensation, or water penetration (including leakages) [3]. However, the most dominant type of dampness was found to be rising dampness as it was identified with many of the buildings surveyed [3]. Hygroscopic salts that led to surface efflorescence, decayed skirting, dampness below $1.5 \mathrm{~m}$, and mold growth on walls up to $1 \mathrm{~m}$ high were among the symptoms identified with rising dampness in the surveyed buildings. The study recommended a more detailed investigation on selected buildings to identify the root cause of the problem.

This paper involves a laboratory study to examine the problem of rising damp and salt attack in the walls of residential buildings. It sought to determine the types of soluble salts and their concentrations in the soils and accumulated percentages in the walls over time and whether there exists any linkage between the salts in the walls and those in the ground. Two buildings in different geological settings in Kumasi, Ghana, were selected as case studies.

\section{Literature Review}

Rising damp is one of the most severe phenomena that leads to decay and deterioration of both old and modern types of buildings $[4,5]$. It is a well-known phenomenon around the world and occurs when groundwater flows and 
rises through porous masonry materials [6]. For several years now, researchers across the world have identified the deterioration at the base of walls as a problem related only to the phenomenon of rising damp, and the focus of remedial treatments has been on the installation of dampproof courses (DPCs) [7-10]. However, in countries where the climate is hotter and drier and the soils are more saline, there are greater rates of water evaporating from the walls of buildings leading to accumulation of soluble salts at the evaporation zone in the masonry [11]. The results of this problem lead to two main problems-rising damp and salt attack [11].

According to Ahmed and Abdul Rahman [12], the problems of rising damp and salt attack are closely related since moisture from rising damp can dissolve existing salts in a building material. Groundwater may sometimes contain salt and can find its way through the walls of a building by capillary action [12]. The water rises up the wall, about a metre or more high, and often deposits a horizontal "tide mark" [13]. Below this mark, there is discolouration of the wall with general darkening and patchiness, and there may be mould growth and loose wallpaper. The height to which the absorbed water rises depends on the water absorption capacity of the masonry, how wet the soil is and how quickly moisture can evaporate. The water contains soluble salts (from the ground or dissolved out of the bricks or mortar) and, as the water evaporates, the salts crystallise out on the wall surfaces, often concentrating in the tide mark [13]. There are three preconditions for rising damp: ground contact; ground moisture; and porous construction [8, 14].

In the latter part of the 19th century, the subject of rising dampness and public health became important to researchers [15]. The architect Thomas Worthington described rising damp in his 1892 essay and recommended that a damp proof course (DPC) should be used to disconnect the whole of the foundations from the superstructure [15]. In a detailed study undertaken by the British Research Establishment (BRE), the moisture contents of a total of ninety-four 100 year old properties in the Cardiff Bay area were measured [16]. Rising damp was reported to occur if the moisture content of mortar samples was above $5 \%$ and it was found that $54 \%$ of the properties suffered from rising damp at heights of $0.3 \mathrm{~m}$ above the floor level [15]. In a study by Trotman et al. [17], it was reported that soluble salts were drawn up into the structures affected by rising damp and became deposited in the walls. When the water evaporated and the salt solution became more concentrated at the surface and crystallised out of solution, blocked the pores, reduced evaporation, and raised the height of the level of dampness. In Greece, MaravelakiKalaitzaki et al. [18] revealed that the main reasons for deterioration of construction materials were attributed to salt crystallization, water, and movement of salt solutions through walls by capillarity. Moreno et al. [19] undertook a detailed study of salt damage on a 16th-17th century church building by sampling from many heights and locations for analysis to build up a full picture of salt damage. The main conclusions were that salts had been introduced by rising damp. The World Health Organization [20] also revealed that in Europe 10-50\% of indoor environments are associated with dampness, and rising damp was reported as the main cause of the dampness problem.

Salts normally present in buildings are either present in the masonry at the time of construction or are absorbed from the atmosphere or ground water during the life of the building $[21,22]$. Salt will crystallize at different heights on walls with rising damp depending on their solubility [23, 24]. Arnold [25] synthesized this distribution from a careful analysis and observation of many damp structures. The distribution of salts within a wall is also dependent on the actual mixture of salts present and their origin. On the basis of a thorough analysis of the north façade of a former convent in northern Bavaria and other monuments, Steiger et al. [26] identified the presence of nitrate, potassium, magnesium, chlorides, and sodium to be associated with rising dampness. The zone of maximum enrichment, around 2-3 $\mathrm{m}$ from the ground, reflected the capillary rise height. Sulphates are reported to be present in many bricks, stones, Portland cement, and some groundwater and are formed in masonry from sulphur dioxide and sulphurous acid in the atmosphere [21].

Different types of soluble salts cause damages to masonry walls. The most common building damaging salts consist of anions-sulphates, chlorides, and nitrates [27]. Also, sodium chloride, magnesium chlorides, sodium nitrates, and sulphates of calcium, sodium, magnesium, and potassium are damaging $[12,28]$. After these salts build up in the plaster and on brick surfaces over a period, they attract moisture from the atmosphere [12] and result in plaster peel-off in a belt. The causes of decay and deterioration of buildings are influenced by the existence and movement of water and damaging salts [29-31].

Dealing effectively with the problem of dampness requires the adoption of an organized system of investigative procedures to confirm all the sources and ensure that the recommended remedial works are appropriate [32]. According to Burkinshaw and Parrett (2004), such a system must commence with identifying and recognizing symptoms or signs of dampness. The selection of an effective remedy for any form of dampness must start with a correct diagnosis of the cause [32]. There are four major stages to any dampness investigation (Figure 1) $[2,11,33]$. These are visual inspection, investigations using moisture meters (nondestructive tests), a more detailed investigation (destructive tests) and homing in on the problem (laboratory assessment study) $[2,11,33]$.

The visual investigation stage requires the surveyor to inspect the defect closely and act as a preliminary assessment for further investigation and confirmation of the defect assessed [2]. In this stage, the identification of a dampness problem is dependent on symptoms such as staining of water, cracking, rotten timber, decay, and blisters, and the diagnosis requires knowledge of the behaviour of relevant building materials, construction knowledge, and knowledge of the use (past, present, and future) of the building.

In stage 2, the most widely used instrument for the diagnosis of dampness in buildings is the moisture meter [2, 11, 12]. Multifunctional moisture meters that feature a resistance function, a capacitance function, a humidity sensor, an air thermometer, a surface thermometer, and deep probe facility are now available on the market. This technique 


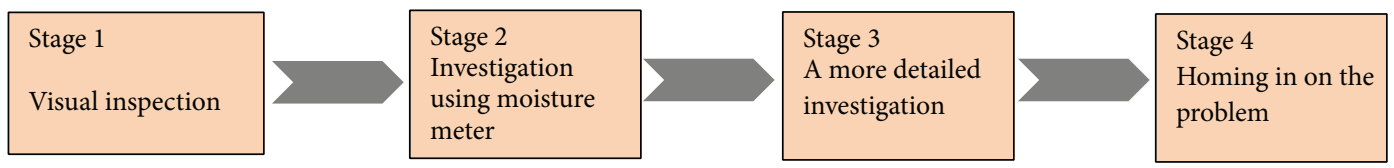

FIGURE 1: The four-stage approach to dampness investigation (sources: $[2,11,32,33]$ ).

may be used to inspect or observe materials or elements of construction in place without causing alteration, damage, or destruction to the fabric of the building $[2,11,33]$.

Stage 3 investigation requires a collection of techniques that may be used to inspect or observe materials or elements of construction in place and it involves causing alteration, damage, or destruction to the fabric of the building. Tools or techniques that are used involve cutting pieces of materials, drilling, salt test, carbide meter, electronic-thermo hygrometer, and mechanical hygrometer $[2,11]$. Oven drying method which is the most accurate method of determining the moisture content of material involves taking samples, weighing and drying the samples to constant weight in an oven at a suitable temperature $\left(100^{\circ} \mathrm{C}\right)$, and then reweighing. The dampness is expressed by the weight loss achieved through drying as a percentage of the oven dry weight of the material being examined $[2,11]$.

In stage 4 , destructive tests and examinations that require opening up are conducted. More emphasis is placed on the sampling which aims at confirming moisture conditions within structural elements (primarily walls and floors) by drilling out masonry samples [2]. The decision on where samples are drilled depends on the kind of investigation undertaken and prevailing site conditions [2]. A typical investigation could first involve sampling at various positions laterally to confirm a damp zone, followed sometimes by vertical sampling where damp patches extend upwards. A typical stage 4 investigation of an average-sized house with very average moisture conditions could involve drilling 10-12 holes [2]. This current study was carried out using stages 3 and 4 investigations to examine the problem of rising damp and salt attack in the walls of residential buildings following earlier studies involving stages 1 and 2 approaches.

\section{Methodology}

This study sought to examine the problem of rising damp and salt attack in the walls of two residential buildings reported to be experiencing severe dampness problems using stages 3 and 4 dampness investigation approaches $[2,7,11,12]$. The survey building in case study 1 is a semidetached building that belongs to the Department of Urban Roads in Kumasi, Ghana (Figure 2(a)). It was constructed between the years 2002 and 2006 and occupied in the year 2007 and has suffered from the problem of dampness for 6 years. Case 2 is a three-bedroom detached building that was sited near a water body and constructed between the years 2004 and 2010 and occupied in 2013 and has also suffered from dampness for 5 years (Figure 2(b)).
The study adopted methods which have been used in previous studies $[2,11,12,33,34]$. Both primary and secondary data were collected. The secondary data included reports and maps from the Soils and Geological Divisions of the Building and Roads Research Institute (BRRI) of the Council for Scientific and Industrial Research (CSIR), Ghana. The secondary sources helped in determining the location of the selected building site, vegetation and climate of the areas, geological settings, and so forth.

3.1. Sampling of Soil. Ground investigations were carried out in accordance with BS 5930 [35] "Code of Practice for Site Investigations," and involved desk study, walk-over survey, trial pit excavation, and soil samples collection. The walkover survey was undertaken to assess the sites, determine the drainage conditions of the sites and its environs, and enable prudent areas to be located for the trial pits.

Two trial pits were manually excavated using pickaxe, shovel, sacks, and measuring tape. Trial pits were chosen because of the lack of access to the building sites which made it difficult for the safe use of borehole rigs. Also, the buildings in Cases 1 and 2 were all three-bedroom single storey structures situated on fairly levelled soils. Studies have shown that it is not a normal practice to sink boreholes and carry out soil tests for a single- or two-storey dwelling houses or similar structures since there is usually adequate knowledge of the required foundation depths and bearing pressures in any particular locality. Sufficient information to check the presumed soil conditions of such buildings can usually be obtained from a few shallow trial pits or hand auger borings [36, 37]. All the pits were dug to depths of $1.50 \mathrm{~m}$ and samples were taken, preserved in plastic bags, and clearly labelled for laboratory tests at the Geotechnical Engineering Laboratory of BRRI of the CSIR.

3.2. Sampling of Mortar. The walls of the buildings were constructed with sandcrete blocks, and the joints between the blocks were filled with $150 \mathrm{~mm}$ thick mortar. Mortar samples were selected because it is the dominant path through which damp rises in walls of buildings [6]. The equipment and materials used to obtain the mortar samples included cordless drills, sharp tungsten carbide drill bits, $35 \mathrm{~mm}$ camera film cases for holding samples, plastic resealable sample bags, sharp $65 \mathrm{~mm}$ bolster, small piece of card for collecting dust, PCE MMK1 universal moisture meter with deep probes, rule, note pad, and labels (Figure 3 ).

Three different mortar samples for each case were taken at $300 \mathrm{~mm}$ heights intervals up to the height of visible damp (i.e., $300 \mathrm{~mm}, 600 \mathrm{~mm}$, and $900 \mathrm{~mm}$ ) to provide information about water soluble salts distributions in the walls [2]. 


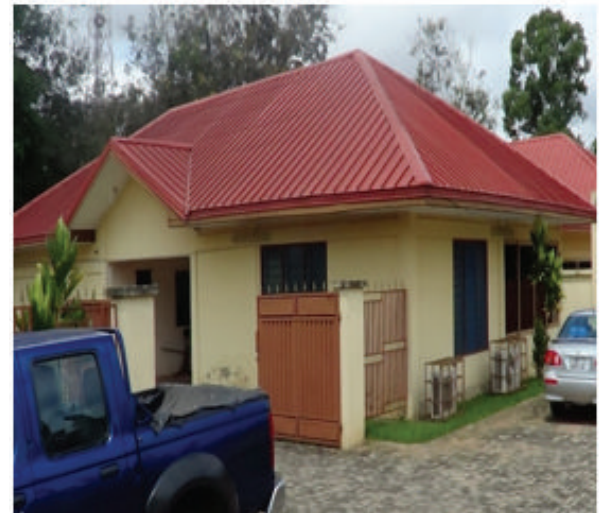

(a)

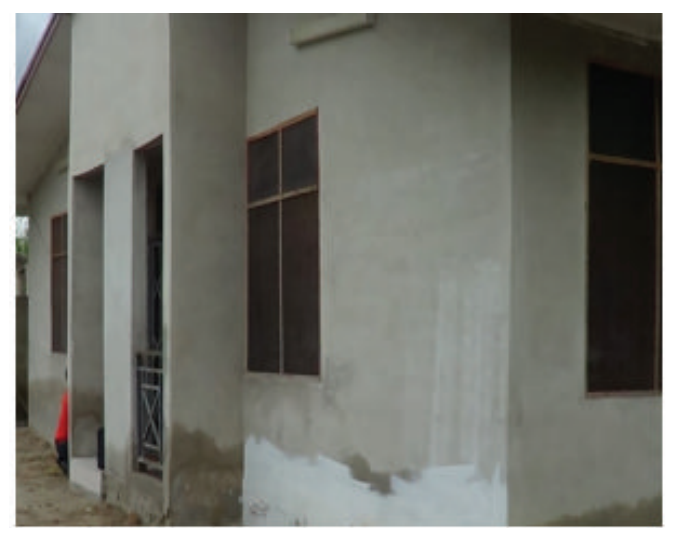

(b)

FIgURE 2: Three-bedroom apartments in Case 1 (a) and Case 2 (b), respectively.

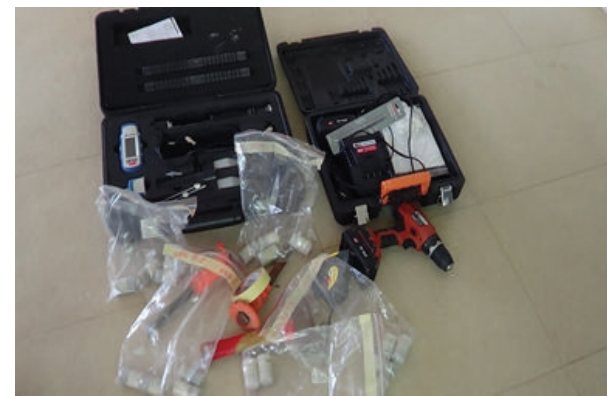

FIGURE 3: Equipment used in the sampling of mortar.

Additional mortar samples for each case were collected about $1.5 \mathrm{~m}$ above the height of visible damp as controls. Mortar samples at depths of $0-25 \mathrm{~mm}, 25-50 \mathrm{~mm}$ and 50$75 \mathrm{~mm}$ were collected for each height (thus $300 \mathrm{~mm}, 600 \mathrm{~mm}$, $900 \mathrm{~mm}$, etc.) for each building, bringing the total number of mortar samples collected to 12 for each building. Mortar samples collected at depths of between $10 \mathrm{~mm}$ and $80 \mathrm{~mm}$ are recommended [38] (Figure 4).

3.3. Analyzing Samples. The soil samples were sent to the Geotechnical Laboratory at the BRRI of the CSIR where tests were conducted in accordance with BS 1377 [39]. Laboratory tests conducted on the soil samples included moisture content, particle size distribution, and Atterberg limits. The moisture content was determined by the oven-dry method. The particle size distribution was carried out in two parts, sieve analysis (to determine the percentage of individual grain sizes present in the soil samples) and sedimentation analysis. The Atterberg limit was conducted to determine the presence or otherwise of clay minerals in the soil deposits.

Mortar and soil samples were also sent to the Chemical Laboratory of the Department of Chemistry, Kwame Nkrumah University of Science and Technology (KNUST), Kumasi, Ghana, for ion chromatography tests. Equipment used in the analysis included ion chromatography (Metrohm 861 Advanced Compact IC), mechanical shaker, $100 \mathrm{~mL}$ measuring cylinder, analytical balance, centrifuge tubes $(15 \mathrm{~mL}$
TABLE 1: Common ions tested in the laboratory and their symbols.

\begin{tabular}{lc}
\hline Ion & $\mathrm{Symbol}$ \\
\hline Fluoride & $\mathrm{F}^{-}$ \\
Chloride & $\mathrm{Cl}^{-}$ \\
Bromide & $\mathrm{Br}^{-}$ \\
Nitrite & $\mathrm{NO}_{2}{ }^{-}$ \\
Nitrate & $\mathrm{NO}_{3}{ }^{-}$ \\
Phosphate & $\mathrm{PO}_{4}{ }^{2-}$ \\
Sulphate & $\mathrm{SO}_{4}{ }^{2-}$ \\
Sodium & $\mathrm{Na}^{+}$ \\
Ammonium & $\mathrm{NH}_{4}{ }^{+}$ \\
Potassium & $\mathrm{K}^{+}$ \\
Calcium & $\mathrm{Ca}^{2+}$ \\
Magnesium & $\mathrm{Mg}^{2+}$ \\
\hline
\end{tabular}

and $50 \mathrm{~mL})$, wash bottles,and volumetric flasks $(2000 \mathrm{~mL}$, $1000 \mathrm{~mL}$, and $100 \mathrm{~mL}$ ) (Figures 5 and 6).

The ion chromatography is a type of liquid chromatography that uses ion exchange resin to separate atomic or molecular ions based on their interaction with the resin. Its greatest utility is for analysis of anions and cations for which there are no other rapid analytical methods available [12]. Conductivity detectors were used to analyse the mortar samples in aqueous form in parts-per-million (ppm) for common anions and cations shown in Table 1.

\section{Results and Discussions}

4.1. General Characteristics of the Soil in the Location. The geotechnical information on the building site showed that the site in Case Study 1 consists predominantly of silty sandy gravel soil with some clay particles. The site in Case Study 2 is predominantly silty sandy soil with some clay and traces of gravel. The average moisture contents of the soils were about $12.55 \%$ and $8.13 \%$ for sites in Cases 1 and 2, respectively. Groundwater was encountered in test pit two of 


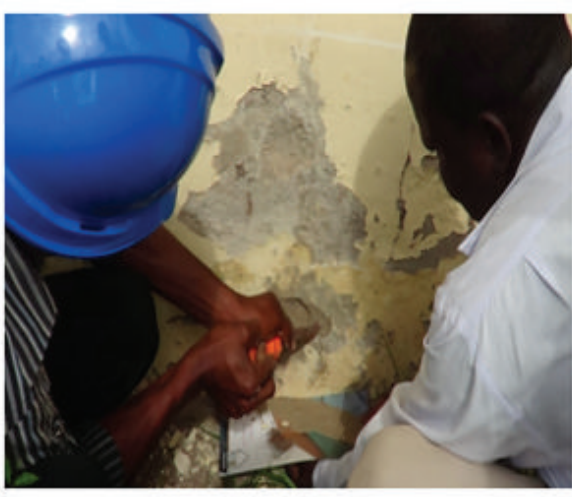

(a)

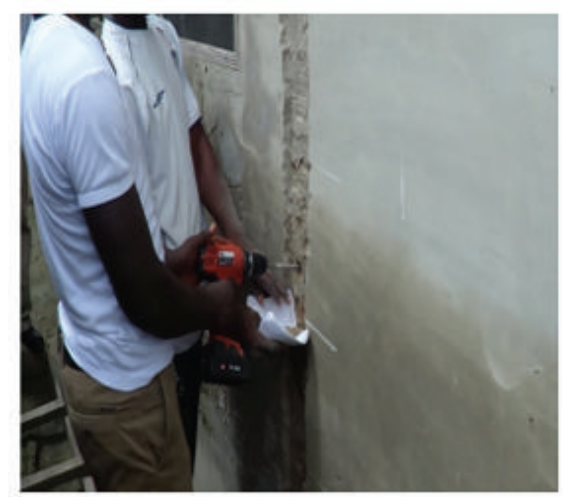

(b)

FIGURE 4: Mortar samples being drilled from buildings in Case 1 (a) and Case 2 (b).

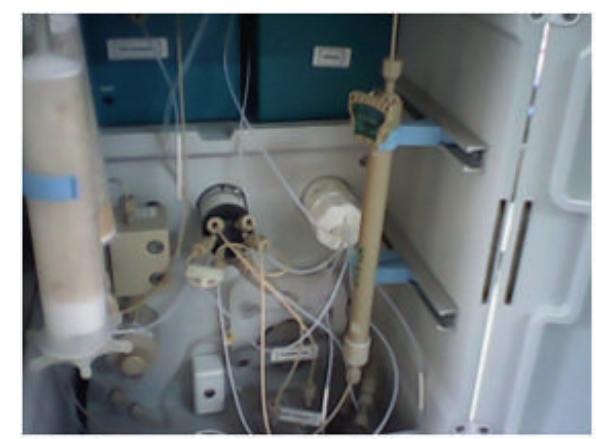

(a)

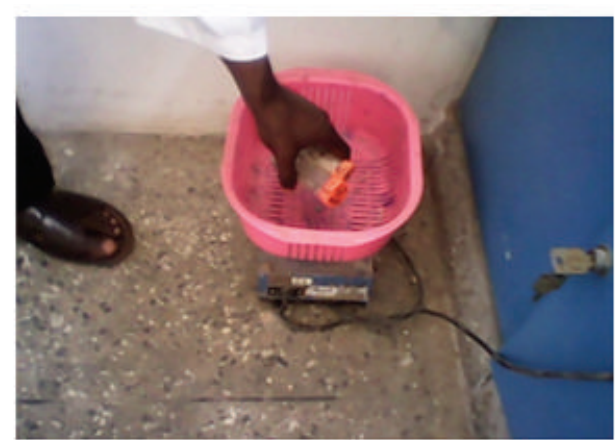

(b)

Figure 5: Mortar samples in Metrohm 861 Advanced Compact IC (a), mortar samples being placed in mechanical shaker (b).

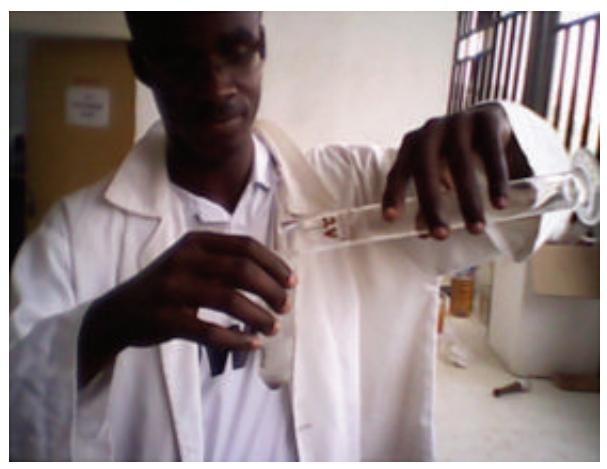

(a)

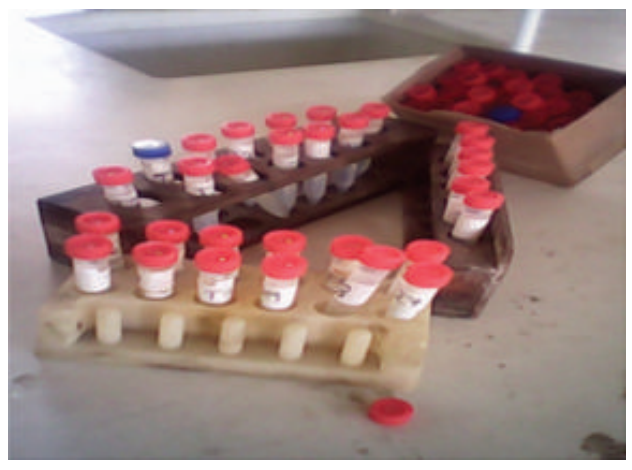

(b)

FIGURE 6: Distilled water being poured from $100 \mathrm{~mL}$ measuring cylinder (a) mortar samples in centrifuge tubes (b).

Case 2 at a depth of $0.47 \mathrm{~m}$. This could be attributed to the fact that this area was closer to a water body. The ground water level was expected to follow the topography of the land surface considering the relatively higher water table. However, ground water was not encountered in test pit one, but the soil was relatively high in moisture and this could be due to water rising from underlying strata or water seeping from the surface.
4.2. Moisture Contents of the Mortar Samples. Figure 7 shows a graphical comparison of moisture contents at different heights of mortar samples for different depths of walls.

The results show that, for the mortar samples collected from all the three depth ranges, moisture contents decreased with increasing heights. Mortar samples collected at heights of $300 \mathrm{~mm}$ in all the cases had the highest moisture content followed by the samples from heights of $600 \mathrm{~mm}$ in that 


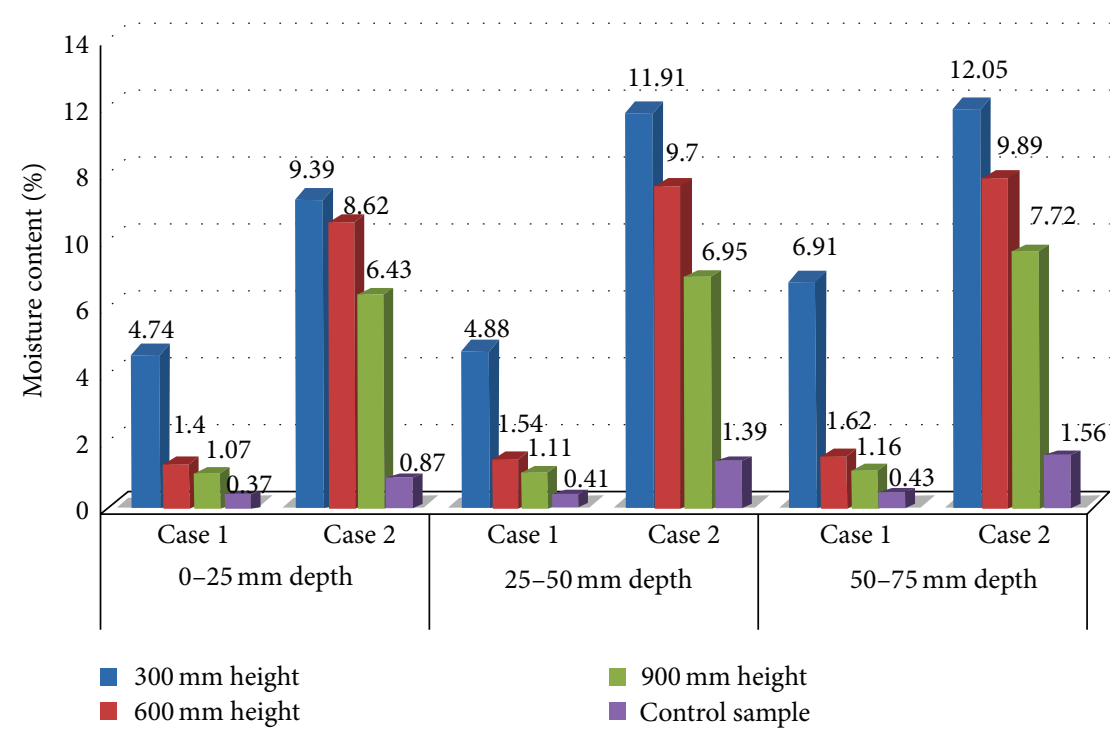

FIGURE 7: Comparisons of moisture content at different heights for differing depth of walls.

order (Figure 7). The results further show that the moisture contents varied with depths. Thus, the moisture contents increased from the depths of $0-25 \mathrm{~mm}$ up to $50-75 \mathrm{~mm}$. Also, the results show that, throughout the various heights in the two cases, moisture contents recorded in Case 2 exceeded those in Case 1.

These higher values recorded for Case 2 indicate that the water body close to the site influenced water ingress into the building. The control samples collected above the height of visible dampness (i.e., $900 \mathrm{~mm}$ ) at the various heights recorded the lowest moisture contents in all the cases. These samples were original and collected above the height of visible dampness. As a result, no significant dampness was found in those areas of the walls. The higher moisture contents recorded at the bases of the walls $(300 \mathrm{~mm})$ indicate a probable source of water ingress from the soil into the buildings. The above results imply that, at the maximum height of visible damp, most of the water in the walls had evaporated leaving behind efflorescent salts, a phenomenon typical of rising dampness [2]. A common source of water that contributes to rising dampness in masonry walls is groundwater [12] and this was responsible for the severity of the dampness in Case 2 compared to Case 1.

4.3. Salts Analysis of Mortar Samples. Results obtained for ionic contents of the mortar samples collected from the two cases are presented in Tables 2 and 3 for samples taken at depths $0-25 \mathrm{~mm}, 25-50 \mathrm{~mm}$, and $50-75 \mathrm{~mm}$ into the walls, respectively.

The results (Table 1) show that, at the maximum height of visible dampness (i.e., $900 \mathrm{~mm}$ ), $\mathrm{Mg}^{2+}$ is the most predominant cation in the mortar samples collected from Case 1 followed by $\mathrm{Na}^{+}$and $\mathrm{K}^{+}$in that order. Percentage concentrations of these ions exceed the acceptable safe limit of $0.020 \%$ $[11,12,34]$ and increase with increasing heights of mortar samples. The anions $\mathrm{SO}_{4}{ }^{2-}$ and $\mathrm{Cl}^{-}$were also predominant at $900 \mathrm{~mm}$ and their percentage concentrations increased with increasing heights of mortar samples. The results further show that, at the maximum height of visible dampness, the percentage concentrations of the most abundant cations and anions appear to decrease with increasing depth of samples. At the various depths (0-25 mm, 25-50 mm, and 50-75 mm) for the maximum height of $900 \mathrm{~mm}, \mathrm{Mg}^{2+}, \mathrm{Na}^{+}$and $\mathrm{K}^{+}$were identified as the most predominant cations and $\mathrm{SO}_{4}{ }^{2-}$ and $\mathrm{Cl}^{-}$as the most predominant anions. The ions identified had total concentrations above the acceptable safe limit of $0.020 \%[11,12,34]$. Thus, magnesium sulphates $\left(\mathrm{MgSO}_{4}{ }^{2-}\right)$, magnesium chlorides $\left(\mathrm{MgCl}_{2}\right)$, sodium sulphate $\left(\mathrm{Na}_{2} \mathrm{SO}_{4}\right)$, sodium chloride $(\mathrm{NaCl})$, potassium sulphate $\left(\mathrm{K}_{2} \mathrm{SO}_{4}\right)$, and potassium chloride $(\mathrm{KCl})$ appear to be the most abundant salts present at the maximum height of visible dampness. These salts are in concentrations likely to cause damage to the wall internally.

The results obtained for the control samples of Case 1 collected at $1.5 \mathrm{~m}$ above the height of visible dampness show that the salt contamination was low on the most predominant anions $\left(\mathrm{SO}_{4}{ }^{2-}\right.$ and $\left.\mathrm{Cl}^{-}\right)$and cations $\left(\mathrm{Mg}^{2+}, \mathrm{Na}^{+}\right.$, and $\left.\mathrm{K}^{+}\right)$. These predominant ions identified had total concentrations below the acceptable safe limit of $0.020 \%$ [11, 12, 34], indicating no significant dampness and damage to the walls. The above results confirm that, at the maximum height of visible damp, most of the water in the soluble salts evaporates leaving behind efflorescent salts.

Results presented in Table 2 also show that $\mathrm{Mg}^{2+}$ is the most predominant cation in the mortar samples collected from Case 2 followed by $\mathrm{Na}^{+}$and $\mathrm{K}^{+}$in that order. Percentage concentrations of these ions exceed the acceptable safe limit of $0.020 \%[11,12,34]$ and increase with increasing heights of mortar samples. The anions, $\mathrm{SO}_{4}{ }^{2-}, \mathrm{Cl}^{-}$, and $\mathrm{NO}_{3}{ }^{-}$, were also predominant at the maximum height of visible dampness (i.e., $900 \mathrm{~mm}$ ) and their percentage concentrations exceed the acceptable safe limit of $0.020 \%[11,12,34]$. The concentrations 
TABLE 2: Results for ionic contents of mortar samples from Case 1.

\begin{tabular}{|c|c|c|c|c|c|c|c|c|c|c|c|c|}
\hline \multirow{2}{*}{ Height of sample } & \multicolumn{5}{|c|}{ Cations } & \multicolumn{7}{|c|}{ Anions } \\
\hline & $\mathrm{Na}^{+}$ & $\mathrm{NH}_{4}^{+}$ & $\mathrm{K}^{+}$ & $\mathrm{Ca}^{2+}$ & $\mathrm{Mg}^{2+}$ & $\mathrm{F}^{-}$ & $\mathrm{Cl}^{-}$ & $\mathrm{Br}^{-}$ & $\mathrm{NO}_{2}^{-}$ & $\mathrm{NO}_{3}{ }^{-}$ & $\mathrm{PO}_{4}{ }^{2-}$ & $\mathrm{SO}_{4}{ }^{2-}$ \\
\hline \multicolumn{13}{|c|}{ Depth 0-25 mm } \\
\hline 300 & 0.022 & 0.000 & 0.013 & 0.010 & 0.060 & 0.001 & 0.065 & 0.000 & 0.000 & 0.005 & 0.000 & 0.110 \\
\hline 600 & 0.036 & 0.000 & 0.027 & 0.001 & 0.068 & 0.000 & 0.082 & 0.000 & 0.000 & 0.014 & 0.000 & 0.103 \\
\hline 900 & 0.086 & 0.000 & 0.039 & 0.003 & 0.106 & 0.005 & 0.086 & 0.000 & 0.000 & 0.018 & 0.000 & 0.165 \\
\hline Control & 0.012 & 0.000 & 0.001 & 0.001 & 0.012 & 0.002 & 0.006 & 0.000 & 0.000 & 0.002 & 0.000 & 0.015 \\
\hline Rank of ions at height $900 \mathrm{~mm}$ & 2nd & 5th & 3rd & 4th & 1st & 4th & 2nd & 5th & 6th & 3rd & 7th & 1st \\
\hline \multicolumn{13}{|c|}{ Depth $25-50 \mathrm{~mm}$} \\
\hline & $\mathrm{Na}^{+}$ & $\mathrm{NH}_{4}^{+}$ & $\mathrm{K}^{+}$ & $\mathrm{Ca}^{2+}$ & $\mathrm{Mg}^{2+}$ & $\mathrm{F}^{-}$ & $\mathrm{Cl}^{-}$ & $\mathrm{Br}^{-}$ & $\mathrm{NO}_{2}{ }^{-}$ & $\mathrm{NO}_{3}{ }^{-}$ & $\mathrm{PO}_{4}{ }^{2-}$ & $\mathrm{SO}_{4}{ }^{2-}$ \\
\hline 300 & 0.032 & 0.000 & 0.013 & 0.006 & 0.035 & 0.005 & 0.061 & 0.000 & 0.000 & 0.004 & 0.000 & 0.052 \\
\hline 600 & 0.039 & 0.000 & 0.016 & 0.008 & 0.069 & 0.001 & 0.063 & 0.000 & 0.000 & 0.015 & 0.000 & 0.107 \\
\hline 900 & 0.042 & 0.000 & 0.029 & 0.003 & 0.086 & 0.004 & 0.107 & 0.000 & 0.000 & 0.016 & 0.000 & 0.144 \\
\hline Control & 0.018 & 0.000 & 0.019 & 0.002 & 0.019 & 0.003 & 0.003 & 0.000 & 0.000 & 0.002 & 0.000 & 0.016 \\
\hline Rank of ions at height $900 \mathrm{~mm}$ & 2nd & 5 th & 3rd & 4th & 1st & 4th & 2nd & 5th & 6th & 3rd & 7 th & 1st \\
\hline \multicolumn{13}{|c|}{ Depth 50-75 mm } \\
\hline & $\mathrm{Na}^{+}$ & $\mathrm{NH}_{4}^{+}$ & $\mathrm{K}^{+}$ & $\mathrm{Ca}^{2+}$ & $\mathrm{Mg}^{2+}$ & $\mathrm{F}^{-}$ & $\mathrm{Cl}^{-}$ & $\mathrm{Br}^{-}$ & $\mathrm{NO}_{2}^{-}$ & $\mathrm{NO}_{3}^{-}$ & $\mathrm{PO}_{4}{ }^{2-}$ & $\mathrm{SO}_{4}{ }^{2-}$ \\
\hline 300 & 0.023 & 0.002 & 0.014 & 0.003 & 0.032 & 0.000 & 0.070 & 0.000 & 0.000 & 0.004 & 0.000 & 0.109 \\
\hline 600 & 0.047 & 0.000 & 0.014 & 0.004 & 0.088 & 0.002 & 0.077 & 0.000 & 0.000 & 0.004 & 0.000 & 0.115 \\
\hline 900 & 0.056 & 0.000 & 0.016 & 0.006 & 0.093 & 0.002 & 0.084 & 0.000 & 0.000 & 0.023 & 0.000 & 0.165 \\
\hline Control & 0.018 & 0.000 & 0.013 & 0.005 & 0.008 & 0.003 & 0.005 & 0.000 & 0.000 & 0.004 & 0.000 & 0.006 \\
\hline Rank of ions at height $900 \mathrm{~mm}$ & 2nd & 5 th & 3rd & 4th & 1st & 4th & 2nd & 5 th & 6th & 3rd & 7th & 1st \\
\hline
\end{tabular}

Note: the italic rows indicate the concentration of the ions at the maximum height of visible dampness (900 mm).

TABLE 3: Results for ionic contents of mortar samples from Case 2.

\begin{tabular}{|c|c|c|c|c|c|c|c|c|c|c|c|c|}
\hline \multirow{2}{*}{ Height of sample } & \multicolumn{5}{|c|}{ Cations } & \multicolumn{7}{|c|}{ Anions } \\
\hline & $\mathrm{Na}^{+}$ & $\mathrm{NH}_{4}^{+}$ & $\mathrm{K}^{+}$ & $\mathrm{Ca}^{2+}$ & $\mathrm{Mg}^{2+}$ & $\mathrm{F}^{-}$ & $\mathrm{Cl}^{-}$ & $\mathrm{Br}^{-}$ & $\mathrm{NO}_{2}{ }^{-}$ & $\mathrm{NO}_{3}^{-}$ & $\mathrm{PO}_{4}{ }^{2-}$ & $\mathrm{SO}_{4}{ }^{2-}$ \\
\hline \multicolumn{13}{|c|}{ Depth $0-25 \mathrm{~mm}$} \\
\hline 300 & 0.018 & 0.000 & 0.016 & 0.005 & 0.057 & 0.001 & 0.008 & 0.000 & 0.000 & 0.004 & 0.000 & 0.018 \\
\hline 600 & 0.021 & 0.000 & 0.020 & 0.002 & 0.097 & 0.001 & 0.039 & 0.000 & 0.000 & 0.004 & 0.000 & 0.056 \\
\hline 900 & 0.091 & 0.014 & 0.046 & 0.001 & 0.197 & 0.001 & 0.069 & 0.000 & 0.000 & 0.085 & 0.000 & 0.263 \\
\hline control & 0.006 & 0.003 & 0.014 & 0.007 & 0.005 & 0.000 & 0.007 & 0.000 & 0.000 & 0.005 & 0.000 & 0.019 \\
\hline Rank of ions at height $900 \mathrm{~mm}$ & 2nd & 4th & 3rd & 5th & 1st & 4th & 3rd & 5 th & 6th & 2nd & 7 th & 1st \\
\hline \multicolumn{13}{|c|}{ Depth $25-50 \mathrm{~mm}$} \\
\hline & $\mathrm{Na}^{+}$ & $\mathrm{NH}_{4}^{+}$ & $\mathrm{K}^{+}$ & $\mathrm{Ca}^{2+}$ & $\mathrm{Mg}^{2+}$ & $\mathrm{F}^{-}$ & $\mathrm{Cl}^{-}$ & $\mathrm{Br}^{-}$ & $\mathrm{NO}_{2}^{-}$ & $\mathrm{NO}_{3}^{-}$ & $\mathrm{PO}_{4}{ }^{2-}$ & $\mathrm{SO}_{4}{ }^{2-}$ \\
\hline 300 & 0.007 & 0.000 & 0.014 & 0.002 & 0.149 & 0.001 & 0.005 & 0.000 & 0.000 & 0.003 & 0.000 & 0.015 \\
\hline 600 & 0.010 & 0.000 & 0.020 & 0.004 & 0.189 & 0.001 & 0.005 & 0.000 & 0.000 & 0.005 & 0.000 & 0.046 \\
\hline 900 & 0.082 & 0.000 & 0.028 & 0.005 & 0.010 & 0.000 & 0.073 & 0.000 & 0.000 & 0.040 & 0.000 & 0.222 \\
\hline Control & 0.018 & 0.000 & 0.017 & 0.001 & 0.004 & 0.001 & 0.013 & 0.000 & 0.000 & 0.014 & 0.000 & 0.016 \\
\hline Rank of ions at height $900 \mathrm{~mm}$ & 1st & 5 th & 2nd & 4th & 3rd & 4th & 2nd & 5 th & 6th & 3rd & 7 th & 1st \\
\hline \multicolumn{13}{|c|}{ Depth 50-75 mm } \\
\hline & $\mathrm{Na}^{+}$ & $\mathrm{NH}_{4}^{+}$ & $\mathrm{K}^{+}$ & $\mathrm{Ca}^{2+}$ & $\mathrm{Mg}^{2+}$ & $\mathrm{F}^{-}$ & $\mathrm{Cl}^{-}$ & $\mathrm{Br}^{-}$ & $\mathrm{NO}_{2}^{-}$ & $\mathrm{NO}_{3}^{-}$ & $\mathrm{PO}_{4}{ }^{2-}$ & $\mathrm{SO}_{4}{ }^{2-}$ \\
\hline 300 & 0.005 & 0.000 & 0.014 & 0.005 & 0.062 & 0.001 & 0.009 & 0.000 & 0.000 & 0.000 & 0.000 & 0.014 \\
\hline 600 & 0.020 & 0.000 & 0.025 & 0.003 & 0.086 & 0.001 & 0.010 & 0.000 & 0.000 & 0.011 & 0.000 & 0.070 \\
\hline 900 & 0.056 & 0.003 & 0.032 & 0.002 & 0.063 & 0.000 & 0.065 & 0.000 & 0.000 & 0.020 & 0.000 & 0.183 \\
\hline Control & 0.017 & 0.000 & 0.017 & 0.001 & 0.011 & 0.000 & 0.012 & 0.000 & 0.000 & 0.013 & 0.000 & 0.004 \\
\hline Rank of ions at height $900 \mathrm{~mm}$ & 2nd & 5 th & 3rd & 4th & 1st & 4th & 2nd & 5th & 6th & 3rd & 7 th & lst \\
\hline
\end{tabular}

Note: the italic rows indicate the concentration of the ions at the maximum height of visible dampness ( $900 \mathrm{~mm})$. 
of these anions increased with increasing heights of mortar samples. The results further show that, at a height of $900 \mathrm{~mm}$, the percentage concentrations of the most abundant cations and anions appear to decrease with increasing depth of samples. At the various depths $(0-25 \mathrm{~mm}, 25-50 \mathrm{~mm}$, and $50-75 \mathrm{~mm}$ ) for the maximum height of $900 \mathrm{~mm}, \mathrm{Mg}^{2+}$, $\mathrm{Na}^{+}$, and $\mathrm{K}^{+}$were identified as the most predominant cations and $\mathrm{SO}_{4}{ }^{2-}, \mathrm{Cl}^{-}$, and $\mathrm{NO}_{3}{ }^{-}$as the most predominant anions. Thus, magnesium sulphates $\left(\mathrm{MgSO}_{4}{ }^{2-}\right)$, magnesium chlorides $\left(\mathrm{MgCl}_{2}\right)$, magnesium nitrate $\left(\mathrm{MgNO}_{3}\right)$, sodium sulphate $\left(\mathrm{Na}_{2} \mathrm{SO}_{4}\right)$, sodium chloride $(\mathrm{NaCl})$, sodium nitrate $\left(\mathrm{NaNO}_{3}\right)$, potassium sulphate $\left(\mathrm{K}_{2} \mathrm{SO}_{4}\right)$, potassium chloride $(\mathrm{KCl})$, and potassium nitrate $\left(\mathrm{KNO}_{3}\right)$ appear to be the most abundant salts present. These salts are in concentrations likely to cause damage to the wall internally.

The results obtained for the control samples in Case 2 collected at $1.5 \mathrm{~m}$ above the height of visible dampness also show that the salt contamination was low on the most predominant anions $\left(\mathrm{SO}_{4}{ }^{2-}, \mathrm{Cl}^{-}\right.$, and $\left.\mathrm{NO}_{3}{ }^{-}\right)$and cations $\left(\mathrm{Mg}^{2+}, \mathrm{Na}^{+}\right.$, and $\left.\mathrm{K}^{+}\right)$. These predominant ions identified had total concentrations below the acceptable safe limit of $0.020 \%$ $[11,12,34]$, indicating no significant dampness and damage to the walls. The results in Case 2 are not much different from those in Case 1.

Salts consist of a combination of positively (cations) and negatively (anions) charged ions, provided there is a balance between these ions [9]. In the formation of salts, not all possible combinations of cations and anions are very soluble and hence damaging [9]. The amount of salt required to cause damage depends on the types of salts, the nature and condition of the masonry, and the cohesive strength of the material [12]. According to Perry and Duffy [27], the most common damaging anions found in buildings consist of sulphates, chlorides, and nitrates.

The salt analysis of the mortar samples in the current study shows that magnesium sulphates $\left(\mathrm{MgSO}_{4}\right)$, magnesium chlorides $\left(\mathrm{MgCl}_{2}\right)$, sodium sulphate $\left(\mathrm{Na}_{2} \mathrm{SO}_{4}\right)$, sodium chloride $(\mathrm{NaCl})$, potassium sulphate $\left(\mathrm{K}_{2} \mathrm{SO}_{4}\right)$, and potassium chloride $(\mathrm{KCl})$ are the most predominant salts present in Case 1. In Case 2, magnesium sulphates $\left(\mathrm{MgSO}_{4}{ }^{2-}\right)$, magnesium chlorides $\left(\mathrm{MgCl}_{2}\right)$, magnesium nitrate $\left(\mathrm{MgNO}_{3}\right)$, sodium sulphate $\left(\mathrm{Na}_{2} \mathrm{SO}_{4}\right)$, sodium chloride $(\mathrm{NaCl})$, sodium nitrate $\left(\mathrm{NaNO}_{3}\right)$, potassium sulphate $\left(\mathrm{K}_{2} \mathrm{SO}_{4}\right)$, potassium chloride $(\mathrm{KCl})$, and potassium nitrate $\left(\mathrm{KNO}_{3}\right)$ appear to be the most abundant salts present. Studies have shown that some of these salts are more damaging than others [9, 40, 41]. Although all the salts identified in the current study can be damaging, $\mathrm{Na}_{2} \mathrm{SO}_{4}, \mathrm{MgSO}_{4}$, and $\mathrm{MgCl}_{2}$ are more damaging and can result in more extensive decay in the walls of the two buildings than all the other salts present $[9,40,41]$.

The results (Tables 2 and 3) also show that most of the salts from the mortar samples are highly concentrated on the wall surface at depth $0-25 \mathrm{~mm}$ than at depths 25$50 \mathrm{~mm}$ and $50-75 \mathrm{~mm}$. This trend means that crystallisation occurred near the surface of affected walls. Bucea et al. [42] found that deterioration of walls of buildings was due to salt crystallization on both concrete exposed to sulphate solution and mortar exposed to either sulphate or chloride solutions.
Bucea et al. [42] further identified that crystallization deterioration was either due to sodium sulphate or a combination of sodium and magnesium sulphates or sodium chloride. The process of crystallization depends on evaporation which is also dependent on environmental conditions [43-45]. Also, the magnitude of the crystallization pressure depends partly on the kind of salt involved, the size and shape of the capillary pore system, and the relative humidity of the surrounding climate [46-49]. Pel et al. [50] reported that high salt concentrations were encountered at the surface of fired clay brick walls as compared to the inner parts of the material. The crystallization of soluble salts in porous materials can generate pressures inside the pores sufficient to exceed the tensile strength and result in material damage. Cracks in walls and increased costs of maintaining walls are among the impacts of salt crystallisation [29, 46, 49]. A chemical analysis of efflorescence salts carried out by Merrigan [51] revealed that sodium sulphate and potassium sulphate salts constituted about $90 \%$ of the main soluble salts identified with buildings in Southern California. Ibrahim et al. [52] tried to determine the effect of sodium sulphate and sodium chloride solutions on the moisture movement of fired clay masonry walls. The study identified that soluble salt attack, especially sodium sulphate solution, resulted in the expansion of the masonry walls which significantly influenced the deterioration of the mortar joints. The rates of failure depended on the types and concentrations of soluble salt [51]. This finding therefore corroborates the literature.

Figures 8 and 9 show that the salt contamination is low in the control samples (healthy mortar) collected from the two cases for all the cations and anions, with percentage ionic concentration less than $0.020 \%$. These samples were original and were collected above the height of visible dampness. As a result, no significant dampness was found in those areas of the walls.

\subsection{Linkage between Salts in the Mortar Samples and in} the Soils. To identify the origin of the salts in the walls of the buildings, salt analysis was conducted on soil samples collected from the two cases. This was to establish whether there exists any linkage between the salts found in the walls of the buildings and those found in the soils. Table 4 shows the results obtained from the laboratory analysis. The results show that sodium chloride, sodium sulphate, sodium nitrate, potassium sulphate, potassium chloride, potassium nitrate, magnesium sulphates, magnesium chlorides, and magnesium nitrate salts were present in the soil samples collected. The figures with asterisk attached refer to the predominant ions at the various depths of the trial pits with percentage concentrations above $0.020 \%$.

Table 5 shows the linkage between the most predominant ions in the mortar and soil samples collected from the two cases. The anions $\left(\mathrm{Cl}^{-}, \mathrm{NO}_{3}{ }^{-}\right.$, and $\left.\mathrm{SO}_{4}{ }^{2-}\right)$ and the cations $\left(\mathrm{Mg}^{2+}, \mathrm{Na}^{+}\right.$and $\left.\mathrm{K}^{+}\right)$were present in both mortar and soil samples. The presence of nitrates, potassium, magnesium, chlorides, and sodium in the walls of buildings are considered to be associated with rising dampness $[12,26]$. This indicates that the more soluble ions, that is, chlorides and nitrates 


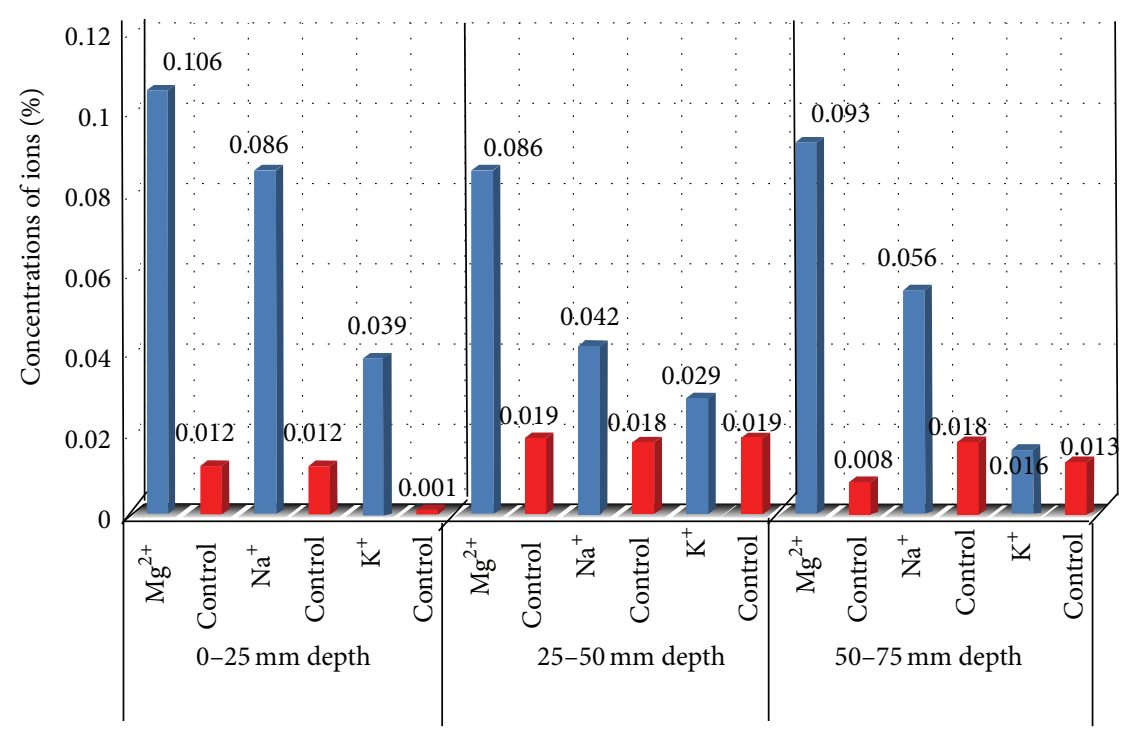

Case 1

(a)

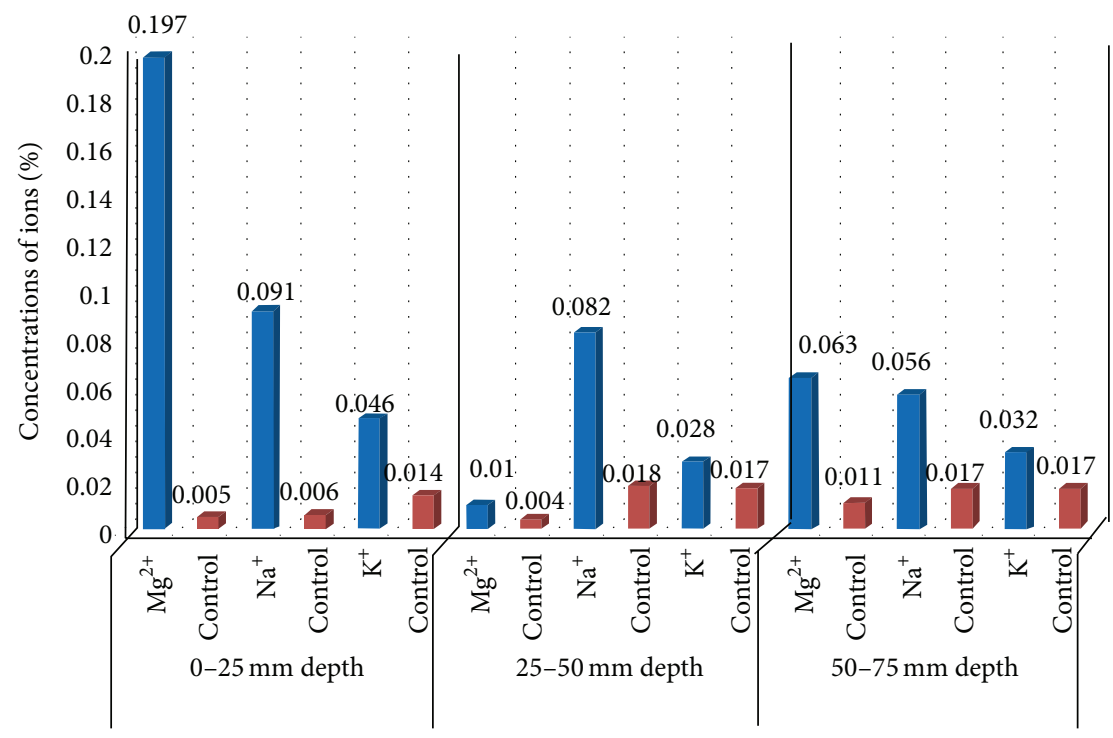

Case 2

(b)

FIGURE 8: Comparison of ionic concentrations of the most predominant cations from Cases 1 and 2 at heights of $900 \mathrm{~mm}$ for different depths.

(Table 5), could partly have been transported into the walls through rising water [12].

The high percentage of magnesium ion in the collected samples could be attributed to the possibility of its abundance in the soil (fine aggregates) used in the preparation of the mortar [12] or the many years of active dampness caused large quantities to accumulate within the walls. The abundance of $\mathrm{Na}^{+}$could be a result of the wicking of ground water by the masonry. This salt is soluble in water and once it is present in the ground it could travel with water into masonry. In addition, the rising water could dissolve and redistribute the salts in the mortar allowing high concentrations of salts to build up [6].
The higher concentration of sulphate ion in the mortar could be attributed to a number of reasons. Sulphate $\left(\mathrm{SO}_{4}{ }^{2-}\right)$ predominant in the mortar samples could have been deposited there partly by ground water and partly by the cement content in the mortar. This is because sulphate ion is normally found in ground water as well as Portland cement [51]. Ground water contains chlorides and nitrates and both salts can cause visual signs of dampness and decorative spoiling on walls when present in abundance [12]. Buchwald and Kaps [31] reported that nitrate and chloride ions of dissolved salts are normally transported into masonries through migrating water, primarily due to rising damp. 


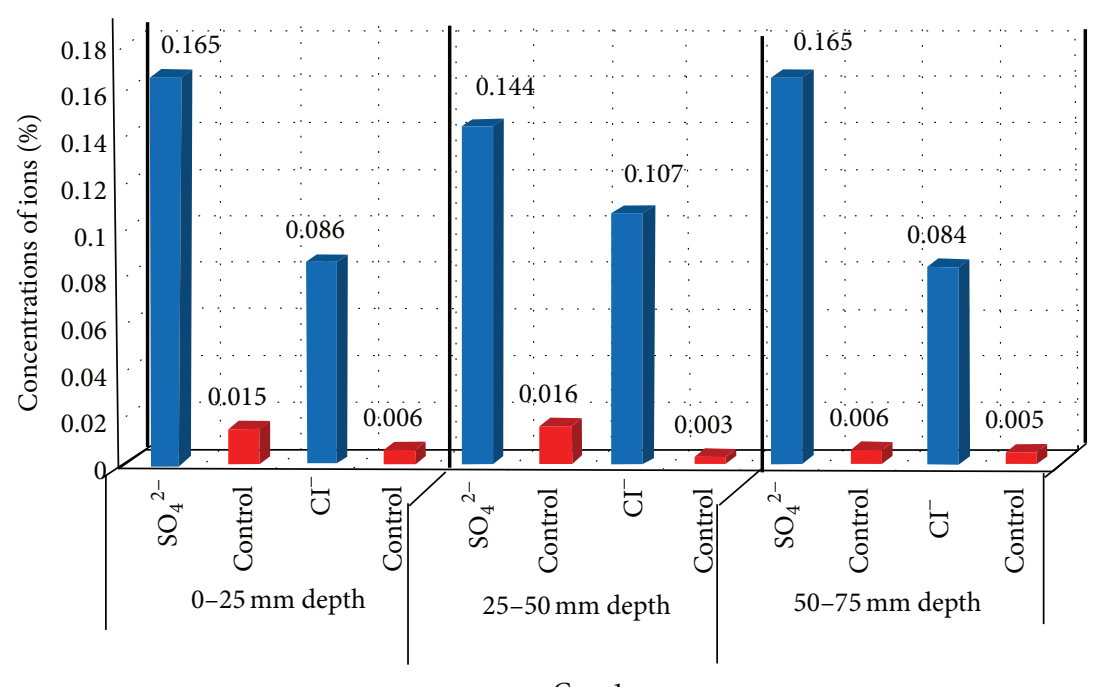

Case 1

(a)

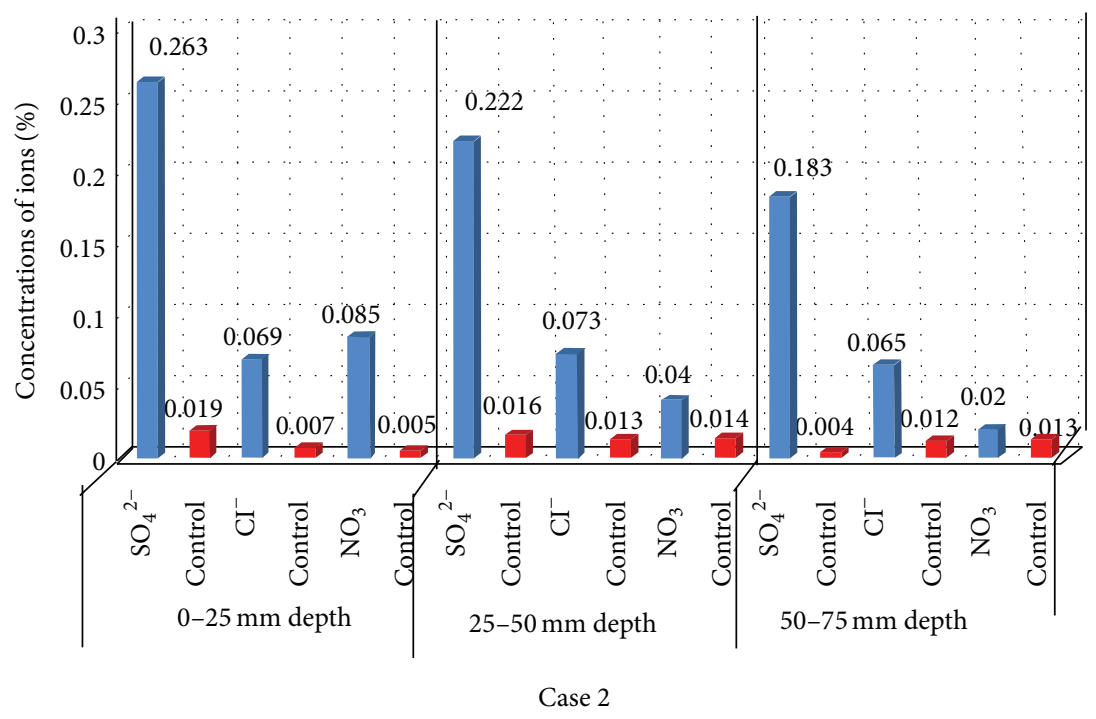

(b)

FIGURE 9: Comparison of ionic concentrations of the most predominant anions from Cases 1 and 2 at heights of $900 \mathrm{~mm}$ for different depths.

\section{Conclusion}

Broad conclusions can be drawn from this study. A holistic approach to dampness investigation was employed to examine the problem of rising damp in the walls of two residential apartments in Kumasi, Ghana. The study sought to determine the types of soluble salts and their concentrations that have accumulated in the soils and the walls of the buildings over time and whether there existed any linkage between the salts in the walls and those from the ground. Results from the geotechnical survey of the building sites found that the soils on site 1 consisted predominantly of silty sandy gravel with some clay particles and those on site 2 consisted of silty sandy soil with some clay and traces of gravel. The study identified the main salts in the walls of the buildings as predominantly magnesium sulphates, magnesium chlorides, magnesium nitrate, sodium sulphate, sodium chloride, sodium nitrate, potassium sulphate, potassium chloride, and potassium nitrate. However, of all these identified salts, the most damaging and dangerous are magnesium sulphate, magnesium chloride, and sodium sulphate salts. The same salts were also identified in the soil samples from the trial pits. The results therefore indicate a linkage between the salts found in the ground and those found in the walls and therefore confirm the presence of rising dampness. Identifying predominant salts in the walls of the affected buildings is critical to the search for appropriate treatment for the rising damp problem. The study recommends more research to be carried out on buildings located within different geographical locations. More laboratory tests and scientific analyses on 
TABle 4: Percentage ionic concentrations of soil samples from Case Study 1 and Case Study 2.

\begin{tabular}{|c|c|c|c|c|c|c|}
\hline \multirow{3}{*}{ Type of ion } & \multicolumn{3}{|c|}{ Case 1} & \multicolumn{3}{|c|}{ Case 2} \\
\hline & & Depth & & & Depth & \\
\hline & $0.3 \mathrm{~m}$ & $0.4 \mathrm{~m}$ & $1.5 \mathrm{~m}$ & $0.3 \mathrm{~m}$ & $0.4 \mathrm{~m}$ & $1.5 \mathrm{~m}$ \\
\hline $\mathrm{F}^{-}$ & 0.000 & 0.001 & 0.001 & 0.000 & 0.000 & 0.001 \\
\hline $\mathrm{Cl}^{-}$ & $0.025^{*}$ & $0.037^{*}$ & $0.211^{*}$ & $0.050^{*}$ & $0.065^{*}$ & $0.120^{*}$ \\
\hline $\mathrm{Br}^{-}$ & 0.000 & 0.000 & 0.000 & 0.000 & 0.000 & 0.000 \\
\hline $\mathrm{NO}_{2}^{-}$ & 0.000 & 0.000 & 0.000 & 0.000 & 0.000 & 0.000 \\
\hline $\mathrm{NO}_{3}^{-}$ & 0.012 & 0.001 & 0.010 & $0.023^{*}$ & $0.034^{*}$ & $0.067^{*}$ \\
\hline $\mathrm{PO}_{4}{ }^{2-}$ & 0.000 & 0.000 & 0.000 & 0.000 & 0.000 & 0.000 \\
\hline $\mathrm{SO}_{4}{ }^{2-}$ & $0.023^{*}$ & $0.027^{*}$ & $0.035^{*}$ & $0.032^{*}$ & $0.047^{*}$ & $0.058^{*}$ \\
\hline $\mathrm{Na}^{+}$ & $0.020^{*}$ & $0.033^{*}$ & $0.042^{*}$ & $0.034^{*}$ & $0.038^{*}$ & $0.044^{*}$ \\
\hline $\mathrm{NH}_{4}^{-}$ & 0.000 & 0.000 & 0.000 & 0.000 & 0.000 & 0.000 \\
\hline $\mathrm{K}^{+}$ & 0.009 & 0.005 & 0.003 & $0.021^{*}$ & $0.030^{*}$ & $0.045^{*}$ \\
\hline $\mathrm{Ca}^{2+}$ & 0.007 & 0.017 & 0.005 & 0.006 & 0.003 & 0.012 \\
\hline $\mathrm{Mg}^{2+}$ & $0.027^{*}$ & $0.053^{*}$ & $0.031^{*}$ & $0.021^{*}$ & 0.005 & 0.000 \\
\hline
\end{tabular}

${ }^{*}$ Predominant ions with percentage concentrations above $0.020 \%$.

TABLE 5: Linkage between salts in mortar and soil samples.

\begin{tabular}{|c|c|c|c|c|c|c|c|c|}
\hline \multirow{3}{*}{ Type of ion } & \multicolumn{4}{|c|}{ Case 1} & \multicolumn{4}{|c|}{ Case 2} \\
\hline & \multirow{2}{*}{ Mortar samples } & \multirow{2}{*}{ Soil samples } & \multirow{2}{*}{$\begin{array}{l}\text { Linkage } \\
\text { Yes }\end{array}$} & \multirow[b]{2}{*}{ No } & \multirow{2}{*}{ Mortar samples } & \multirow{2}{*}{ Soil samples } & \multicolumn{2}{|c|}{ Linkage } \\
\hline & & & & & & & Yes & No \\
\hline $\mathrm{F}^{-}$ & $\bullet$ & • & & & - & • & & \\
\hline $\mathrm{Cl}^{-}$ & $\checkmark$ & $\checkmark$ & Yes & & $\checkmark$ & $\checkmark$ & Yes & \\
\hline $\mathrm{Br}^{-}$ & • & • & & & - & - & & \\
\hline $\mathrm{NO}_{2}^{-}$ & - & • & & & - & • & & \\
\hline $\mathrm{NO}_{3}^{-}$ & $r$ & $r$ & Yes (but in small quantities) & & $\checkmark$ & $\checkmark$ & Yes & \\
\hline $\mathrm{PO}_{4}{ }^{2-}$ & - & - & & & - & • & & \\
\hline $\mathrm{SO}_{4}{ }^{2-}$ & $\checkmark$ & $\checkmark$ & Yes & & $\checkmark$ & $\checkmark$ & Yes & \\
\hline $\mathrm{Na}^{+}$ & $\checkmark$ & $\checkmark$ & Yes & & $\checkmark$ & $\checkmark$ & Yes & \\
\hline $\mathrm{NH}_{4}^{-}$ & - & - & & & - & - & & \\
\hline $\mathrm{K}^{+}$ & $\checkmark$ & $\checkmark$ & Yes & & $\checkmark$ & $\checkmark$ & Yes & \\
\hline $\mathrm{Ca}^{2+}$ & • & • & & & • & • & & \\
\hline $\mathrm{Mg}^{2+}$ & $\checkmark$ & $r$ & Yes & & $\checkmark$ & $r$ & Yes & \\
\hline
\end{tabular}

$\checkmark$ : ions which are present in both mortar and soil samples.

-: ions which are absent in samples or with no significant percentage concentrations.

salts should be carried out to have a better understanding of how to handle the problem of rising damp and salt attacks.

\section{Conflict of Interests}

The authors declare that there is no conflict of interests regarding the publication of this paper.

\section{Acknowledgments}

The authors would like to show their utmost gratitude to the Department of Urban Roads, Kumasi and Mr. Titus Ebenezer Kwofie, for allowing their buildings to be used in this study. The authors also acknowledge the contribution of the staff of the Geotechnical Division of Building and
Road Research Institute (BRRI), Council for Scientific and Industrial Research (CSIR), Kumasi, and Mr. Stephen Boandoh, a postgraduate laboratory assistant at the Department of Chemistry, Kwame Nkrumah University of Science and Technology (KNUST), Kumasi, Ghana, for their great assistance in making this study a success.

\section{References}

[1] U. S. Yilmaz, M. Dereli, S. Korur, and Z. Korkmaz, "Water based damages on building faces and solution proposals," BALWOIS 2010, Ohrid, Republic of Macedonia, pp. 1-7, May 2010.

[2] R. Burkinshaw and M. Parrett, Diagnosing Damp, Rics-Royal Institution of Chartered Surveyors Books, Coventry, UK, 2004.

[3] K. Agyekum, J. Ayarkwa, C. Koranteng, and E. Adinyira, "Preliminary assessment of dampness in walls of residential 
buildings in four climatic zones in Ghana," Journal of Sustainable Development, vol. 6, no. 9, pp. 51-61, 2013.

[4] C. Gentilini, E. Franzoni, S. Bandini, and L. Nobile, "Effect of salt crystallisation on the shear behaviour of masonry walls: an experimental study," Construction and Building Materials, vol. 37, pp. 181-189, 2012.

[5] P. B. Lourenço, E. Luso, and M. G. Almeida, "Defects and moisture problems in buildings from historical city centres: a case study in Portugal," Building and Environment, vol. 41, no. 2, pp. 223-234, 2006

[6] E. Rirsch and Z. Zhang, "Rising damp in masonry walls and the importance of mortar properties," Construction and Building Materials, vol. 24, no. 10, pp. 1815-1820, 2010.

[7] G. Alfano, C. Chiancarella, E. Cirillo, I. Fato, and F. Martellotta, "Long-term performance of chemical damp-proof courses: twelve years of laboratory testing," Building and Environment, vol. 41, no. 8, pp. 1060-1069, 2006.

[8] R. Burkinshaw, "Rising damp: part 1. Case study examples and the Lambeth Pier Test: how to isolate ground-sourced rising damp by the "Burkinshaw Test Method"', Journal of Building Survey, Appraisal \& Valuation, vol. 1, no. 1, pp. 1-15, 2012.

[9] D. Young, Salt Attack and Rising Damp: A Guide to Salt Damp in Historic and Older Buildings, Heritage Council of NSWHeritage, Victoria, Australia, 2008.

[10] D. Young, "The need to get the salt out: dealing with rising damp and salt attack," http://filesdown.esecure.co.uk/Lectros/ Get_The_Salt_Out_David_Young_OAM_BAppSc.pdf_011220081110-45.pdf.

[11] Y. Hamid and S. Ngah, "Assessment of dampness problems in the higher education institution building," in Proceedings of the 12th International Surveyor's Congress (Reaching 50 and Surveying Ahead), Kuala Lumpur, Malaysia, June 2010.

[12] A. G. Ahmed and F. Abdul Rahman, "Treatment of salt attack and rising damp in heritage buildings in Penang, Malaysia," Journal of Construction in Developing Countries, vol. 15, pp. 93113, 2010.

[13] British Research Establishment (BRE), Good Repair Guide 6, Treating Rising Damp in Houses, BRE Press, 1997.

[14] J. Hetreed, The Damp House: A Guide to the Causes and Treatment of Dampness, 2008.

[15] Z. Zhang, A review of rising damp in masonry building.

[16] H. W. Harrison and P. Trotman, Foundations, Basements and External Works, BRE Building Elements, London, UK, 2002.

[17] P. Trotman, C. Sanders, and H. Harrison, Understanding Dampness, BRE Bookshop, 2004.

[18] P. Maravelaki-Kalaitzaki, A. Bakolas, I. Karatasios, and V. Kilikoglou, "Hydraulic lime mortars for the restoration of historic masonry in Crete," Cement and Concrete Research, vol. 35, no. 8, pp. 1577-1586, 2005.

[19] F. Moreno, S. A. G. Vilela, Â. S. G. Antunes, and C. A. S. Alves, "Capillary-rising salt pollution and granitic stone erosive decay in the parish church of Torre de Moncorvo (NE Portugal)implications for conservation strategy," Journal of Cultural Heritage, vol. 7, no. 1, pp. 56-66, 2006.

[20] World Health Organisation, Guidelines for Indoor Air Quality: Dampness and Mould, WHO, 2009.

[21] B. H. Abu Bakar, M. H. Wan Ibrahim, and M. A. Megat Johari, "A review: durability of fired clay brick masonry wall due to salt attack," International Journal of Integrated Engineering, vol. 1, no. 2, pp. 111-127, 2011.
[22] J. W. Jordan, "Factors in the selection of mortar for conservation of histroric masonry," in Proceedings of the 6th Australasian Masonry Conference, Adelaide, Australia, 2001.

[23] A. E. Charola, "Salts in the deterioration of porous materials: an overview," Journal of the American Institute for Conservation, vol. 39, pp. 327-343, 2000.

[24] A. Arnold and K. Zehnder, "Crystallization and habits of salt efflorescences on walls II. Conditions of crystallization," in Proceedings of the 5th International Congress on the Deterioration and Conservation of Stone, G. Felix, Ed., pp. 269-277, Presses Polytechniques Romandes, 1985.

[25] A. Arnold, "Rising damp and saline minerals," in Proceedings of the 4th International Congress on the Deterioration and Preservation of Stone Objects, K. L. Gauri and J. A. Gwinn, Eds., pp. 11-28, University of Louisville, Loiusville, Ky, USA, 1982.

[26] M. Steiger, A. Behlen, H. Neumann, U. Willers, and C. Wittenberg, "Sea salts in historic buildings: deposition, transport and accumulation," in Proceedings of the 4th International Symposium on the 4th InternationalSymposium on the Conservation of Monuments in the Mediterranean Basin, Rhodes, Greece, May 1997.

[27] S. H. Perry and A. P. Duffy, "The short-term effects of mortar joints on salt movement in stone," Atmospheric Environment, vol. 31, no. 9, pp. 1297-1305, 1997.

[28] City of Adelaide, Department of Environment and Natural Resources, 1997, http://www.buildingconservation.com/.

[29] R. M. Espinosa, L. Franke, and G. Deckelmann, "Phase changes of salts in porous materials: crystallization, hydration and deliquescence," Construction and Building Materials, vol. 22, no. 8, pp. 1758-1773, 2008.

[30] L. A. Rijniers, L. Pel, H. P. Huinink, and K. Kopinga, "Salt crystallization as damage mechanism in porous building materials-a nuclear magnetic resonance study," Magnetic Resonance Imaging, vol. 23, no. 2, pp. 273-276, 2005.

[31] A. Buchwald and C. Kaps, "The ion mobility of deteriorating salts in masonry materials of different moisture content, materials for building and structures," in Proceedings of the European Congress on Advanced Materials and Processes in conjunction with the Exhibition Materialica (Euromat '99), vol. 6, pp. 157162.

[32] S. Carillion, Defects in Buildings: Symptoms, Investigations, Diagnosis and Cure, The Stationary Office, London, UK, 2001.

[33] A. A. Halim, S. N. Harun, and Y. Hamid, "Diagnosis of dampness in conservation of historic buildings," Journal of Design + Built, vol. 5, 2012.

[34] E. Borrelli, Conservation of Architectural Heritage, Historic Structures and Material, ARC Laboratory Handbook, ICCROM, 1999.

[35] British Standard Code, BS 5930:1999 Code of Practice for Site Investigations, 1999.

[36] American Society of Civil Engineers (ASCE), "Subsurface investigation for design and construction of foundations of buildings," Manuals and Reports on Engineering Practice 56, 1976.

[37] American Society of Civil Engineers (ASCE), Subsurface Exploration for Underground Excavation and Heavy Construction, Proceedings of a Specialty Conference, American Society of Civil Engineers, 1974.

[38] R. Burkinshaw, "Rising damp: part 1. Case study examples and the Lambeth Pier Test: how to isolate ground-sourced rising damp by the "Burkinshaw Test Method"', Journal of Building Survey, Appraisal \& Valuation, vol. 1, no. 1, pp. 1-15, 2011. 
[39] "British Standard Code. Methods of tests for soils for civil engineering purposes," Tech. Rep. BS 1377, 1990.

[40] H. de Clercq, "The effect of other salts on the crystallization damage to stone caused by sodium sulphate," in Proceedings of the Salt Weathering on Buildings and Stone Sculptures, pp. 22-24, Copenhagen, Denmark, October 2008.

[41] S. Zsembery, Manual 2: The Properties of Clay Masonry Units, Clay Brick and Paver Institution, Baulkham Hills, Australia, 2001.

[42] L. Bucea, V. Sirivivatnanom, and R. Khatri, "Building materials deterioration due to salt attack," Laboratory Experimental Program, Internal Technical Report, CSIRO Manufacturing and Infrastructure Technology, 2005.

[43] B. Lubelli, R. P. J. van Hees, and C. J. W. P. Groot, "Sodium chloride crystallization in a "salt transporting" restoration plaster," Cement and Concrete Research, vol. 36, no. 8, pp. 1467-1474, 2006.

[44] R. Snethlage and E. Wendler, "Moisture cycles and sandstone degradation," in Saving Our Architectural Heritage: The Conservation of Historic Stone Structures, N. S. Baer and R. Snethlage, Eds., pp. 7-24, John Wiley \& Sons, Chichester, UK, 1997.

[45] S. Z. Lewin, "The mechanism of masonry decay through crystallization," in Conservation of Historic Stone Buildings and Monuments, pp. 120-144, National Academy Press, Washington, DC, USA, 1978.

[46] D. Benavente, J. Martínez-Martínez, N. Cueto, and M. A. García-del-Cura, "Salt weathering in dual-porosity building dolostones," Engineering Geology, vol. 94, no. 3-4, pp. 215-226, 2007.

[47] T. T. Van, K. Beck, and M. Al-Mukhtar, "Accelerated weathering tests on two highly porous limestones," Environmental Geology, vol. 52, no. 2, pp. 283-292, 2007.

[48] M. Steiger, "Salts in porous materials: thermodynamics of phase transitions, modelling and preventive conservation," Restoration of Buildings and Monuments, vol. 11, no. 6, pp. 419-431, 2005.

[49] A. La Iglesia, V. González, V. López-Acevedo, and C. Viedma, "Salt crystallization in porous construction materials I estimation of crystallization pressure," Journal of Crystal Growth, vol. 177, no. 1-2, pp. 111-118, 1997.

[50] L. Pel, H. Huinink, and K. Kopinga, "Salt transport and crystallization in porous building materials," Magnetic Resonance Imaging, vol. 21, no. 3-4, pp. 317-320, 2003.

[51] P. E. Merrigan, "Efflorescence, causes and control," The Masonry Society Journal, vol. 5, no. 1, 1986.

[52] M. H. W. Ibrahim, B. H. Abu Bakar, M. A. Megat Johari, R. Putra Jaya, and M. F. Ashad, "The Effect of sodium sulphate and sodium chloride solutions on the moisture movement of fired clay masonry wall," International Journal of Sustainable Construction Engineering and Technology, vol. 2, no. 1, pp. 11-23, 2011. 

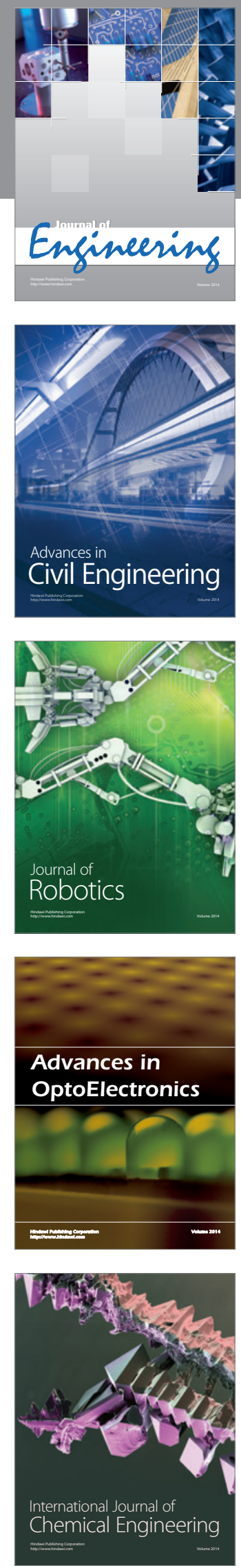

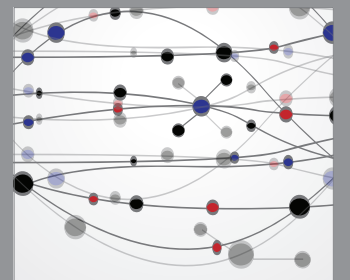

The Scientific World Journal
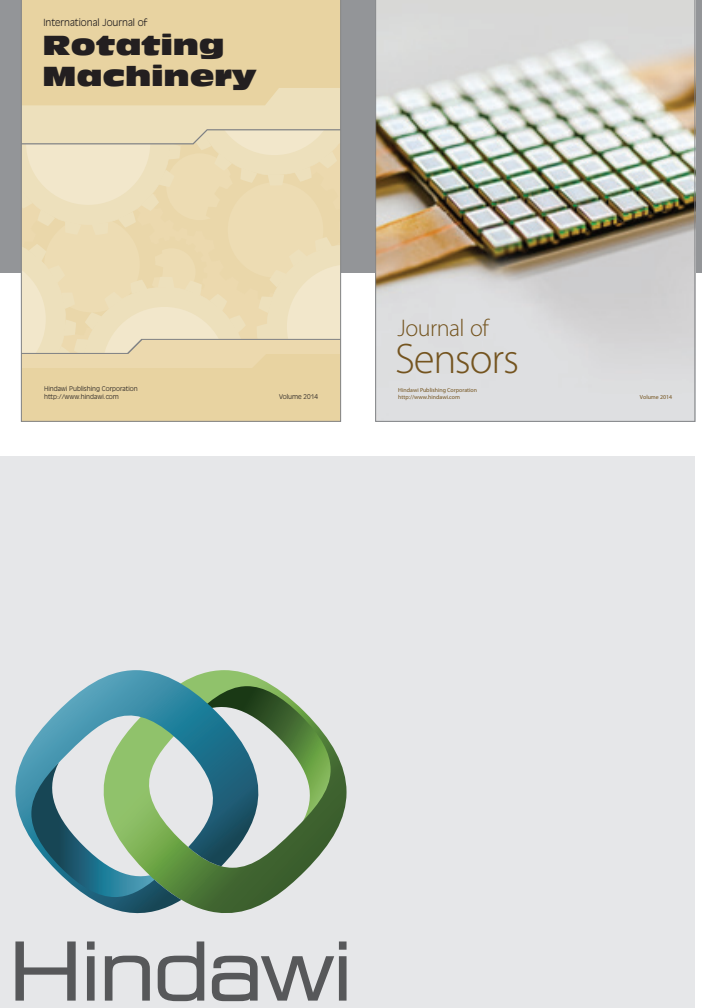

Submit your manuscripts at http://www.hindawi.com
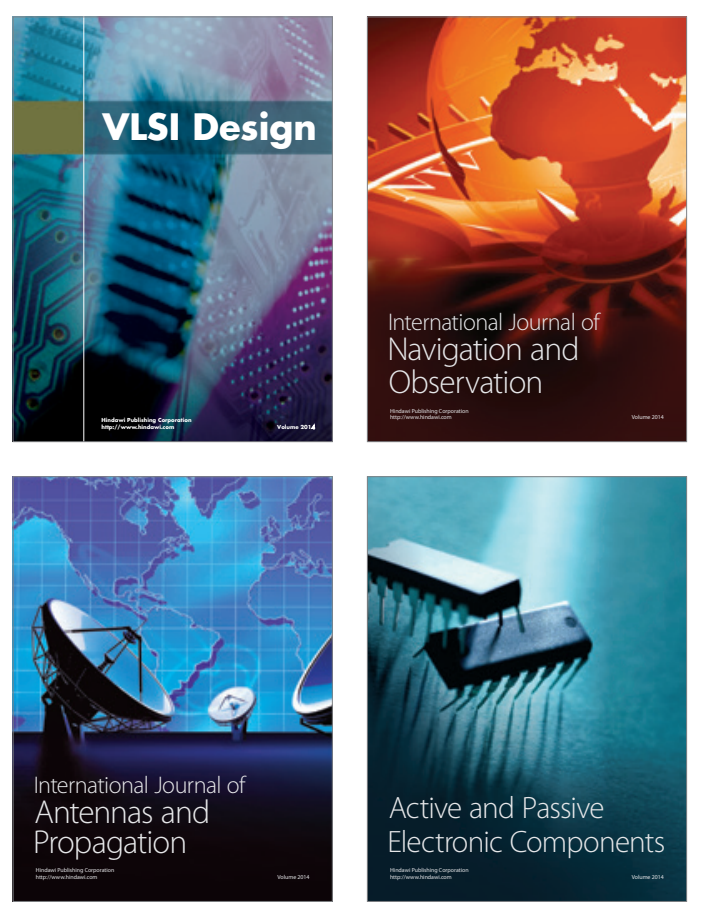
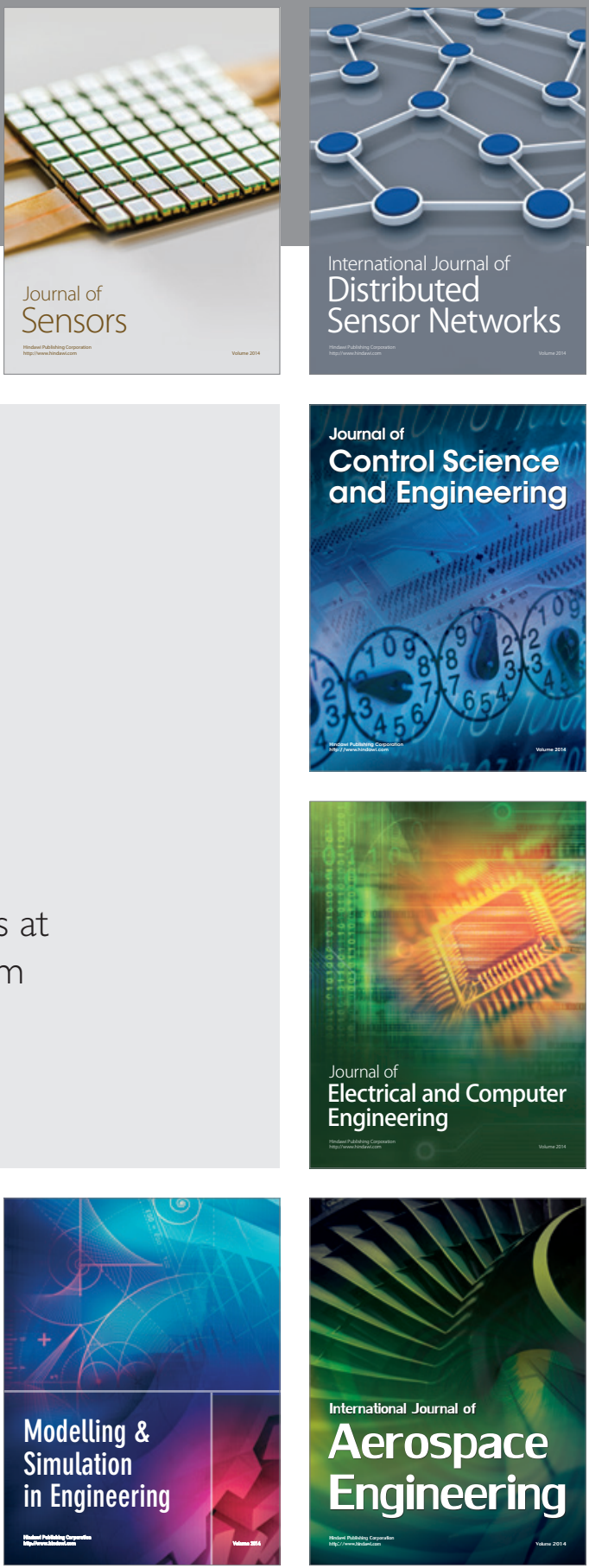

Journal of

Control Science

and Engineering
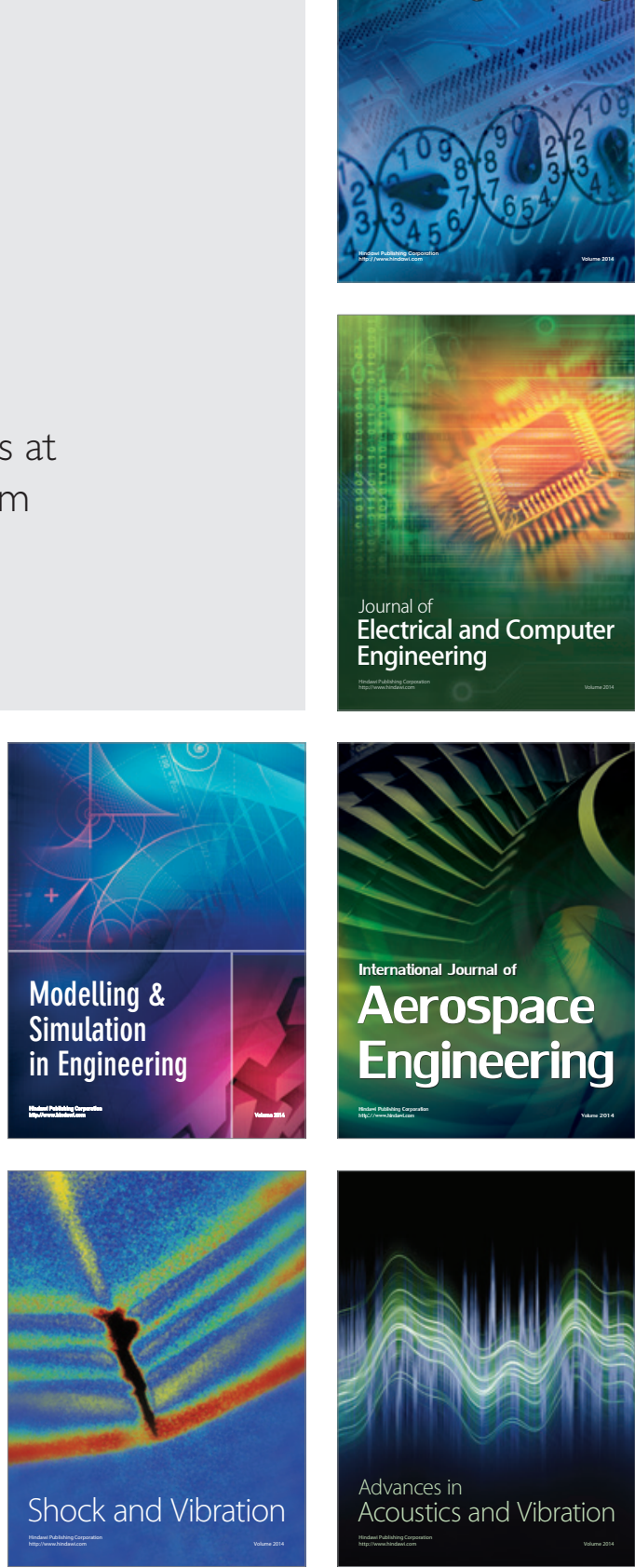